\title{
Pandemic, but Make It Fashion: Ukrainian Embroidered PPE in the Time of COVID-19
}

\author{
Katya Chomitzky \\ University of Alberta \\ Edmonton, Canada
}

\section{Abstract}

Embroidered pandemic wear has become one of the newest cultural fashion trends to emerge in Ukraine and within its Canadian diaspora. This article explores the ways in which embroidery as a traditional form of culture retains meaning within modern contexts, while also serving as a vehicle for experimenting with atypical applications of cultural symbols and representations. Throughout the COVID-19 pandemic, cloth masks have been recommended by public health officials, including the World Health Organization, as a preventative measure to limit the spread of the virus. On the basis of digital fieldwork, I discuss the meanings and inspirations behind these embroidered masks, while conducting a material culture analysis of the objects themselves. I argue that, through a subversion of their common purpose - to hide one's identity - masks have been used in the pandemic as an open/performative display of culture. I contend that this display acts as a means to promote tradition through ephemera and assert cultural importance. This, coupled with the personal/private use of embroidery as a protective talisman, has fueled a trend of embroidered personal protective equipment in popular culture. In this article, I examine the purpose, use, and form of these masks in order to bring light to the ways in which cultural traditions and objects act (and developed prevalence) as a form of pandemic response.

Introduction

As an integral part of Ukraine's national cultural history, embroidery retains a prolific heritage through its use in folklore, traditional costume, and various household and spiritual objects. The newest form of ephemera to be adorned with the traditional stitches and patterns is that of face masks worn during the COVID19 crisis. Scholars, including Robert Klymasz [1987], Shawna Lemiski [1994], and Olena Vasylivna Shevchenko [2018], have outlined the cultural significance of traditional embroidery patterns, the act of embroidery as well as the folklore surrounding them within the Ukrainian context. More recently, during the COVID-19 pandemic, the traditional art of Ukrainian embroidery has begun to appear on face masks and other forms of personal protective equipment (hereafter PPE) recommended by public health officials to limit the transmission of the virus. (1) While this article does not explore the effectiveness of face masks in 
preventing the spread of COVID-19, it does examine how those masks are adorned in Ukrainian culture. With face masks and various forms of PPE bearing this cultural identifier, a variety of techniques have been utilized to create or replicate traditional embroidery patterns. For example, some artists and designers have begun to use faux embroidery (2) in order to protect the integrity of the fabric [see Image 1]. To avoid creating tiny holes in the top layer of the cloth with the embroidery needle, some favor the use of vinyl transfers on fabric or painted-on depictions of crossstitched styles.

While these masks function on a number of levels, this article focuses on the use of embroidery on masks as a traditional protective symbol

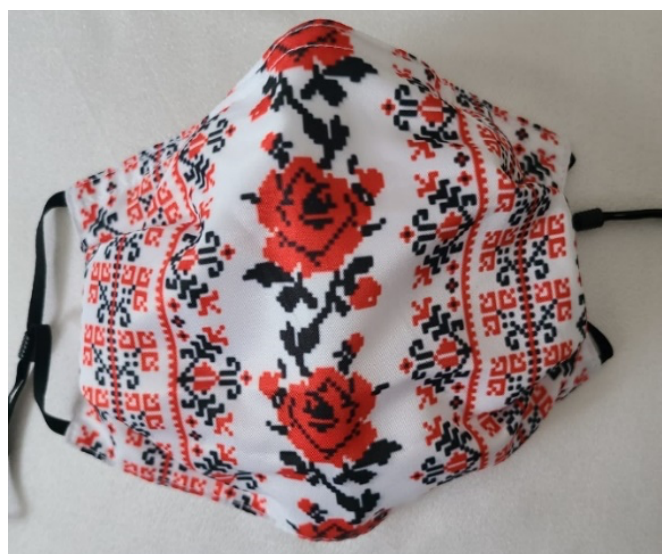

Image 1. Silk screened onto the fabric, the pattern on this mask mimics the cross-stitch technique of embroidery in a common geometric floral print featuring roses and intricate lines in black and red. and as a symbol of Ukrainian macro-identity through the open/performative function of folk art. Here, I explore the traditional cultural beliefs surrounding embroidery patterns as protective symbols, the identity politics that inform open/performative displays of culture, and the subversion of traditional uses of masks as a form of identity concealment in this pandemic. By addressing these phenomena, this article examines the function of embroidered masks as folkloric cultural ephemera within Ukrainian national and Canadian diasporic contexts. This research is valuable as it not only focuses on a new and pressing global phenomenon, but also contributes to longstanding discussions about the general role of embroidery. Ukrainian embroidery has only been re-popularized in society and fashion since the first celebration of World Vyshyvanka [embroidered shirt] Day in 2006. Since then, embroidery has been used as a symbol of cultural unification and identification, a trend that was particularly visible during the 2013-2014 Euromaidan Revolution of Dignity. Following this resurgence of embroidery in popular fashion, there has also been an increase in the presence of traditional and modern embroidery in Ukrainian diaspora, particularly within Canada, demonstrating a valuable transnational connection of material culture.

In her Master's thesis "The Embroidery of Vyshyvanka: From Traditional Technique to Contemporary Technologies," Kseniia Snikhovska asserts that the popular resurgence of embroidery in Ukraine is due to the use of embroidery as a "manifestation and a symbol of [Ukrainian] national identity" [2017: 5]. While this same incentive exists when people choose to wear embroidered masks, I 
believe that there are three primary functions that such embroidery serves which contribute to the overall popularity of culturally decorated PPE; those items also serve as a sign of patriotism and cultural recognition, a fashion statement, and, perhaps less prominently, as a talisman or symbol of protection in regards to the personal/private function of embroidery.

To fully explore the impact of Ukrainian embroidered face masks within the macro-culture of Ukrainian society, both national and diasporic, we must first investigate the two groups responsible for the popularity of the masks: the creators and the consumers. To better analyze these groups and their role within the trend, I have conducted two brief surveys, one directed towards the consumers who wear and purchase masks with embroidery or Ukrainian symbols, and a second directed at the artisans and designers who create the masks. Both surveys were distributed to Ukrainian nationals and Ukrainian Canadians. Prior to receiving responses, I had hypothesized that cultural pride would act as an influencing factor in the choice to purchase or create these masks. I argue that cultural ephemera work to build community and preserve traditional forms of folk art within the COVID-19 pandemic, a trend that may be both revealing and valuable for the larger sphere of material culture studies and studies of traditional folk art adaption and preservation.

\section{Background}

As a form of "informal, expressive culture" [Kule Folklore Centre 2011], a standard definition of folklore, Ukrainian embroidery occupies a unique space in the study of material culture. This form of folk art is traditionally found on objects such as vyshyvanky [embroidered shirts] and rushnyky [ritual cloths], as well as applied to other household objects, such as ceramics, through the process of decalcomania (the process of transferring designs from prepared paper, such as vinyl, onto another object). Embroidery, as a cultural medium, functions on two main levels, open/performative and personal/private. The open/performative nature of embroidery functions on a similar level to performative culture. Maksym Karpovets' emphasizes that when we think of performance, we tend to focus on the theatrical elements of what it means to entertain, but the "...увагу людини на специфічній естетичній та емоційній взаємодії між артистом і аудиторією” [attention to a specific aesthetic and emotional interaction between the artist and the audience] [Karpovets' 2018: 140] that is integral to all performance, is the same focus and interaction which informs displays of embroidery. In embroidery, though, the role of the artist is often removed with connection being created instead between the wearer and their audience. The open/performative nature of culture exists when the object in question displays a message to those who view it. Robert Klymasz [1987: 4] describes "the public function of Ukrainian embroidery... as a form of open display to underline a fidelity to ethnic loyalty and origin." With the familiarity of embroidered symbols and patterns within Ukrainian culture, displaying identity is at the forefront of mask wearing as cultural ephemera. The second function, personal/private, focuses on the 
protective elements of masks and the beliefs, both sacred and secular, that accompany certain patterns. While these two functions can exist separately, they do not contradict or oppose one another and often exist concurrently within folkloric material culture. Additionally, these functions act as motivators for those

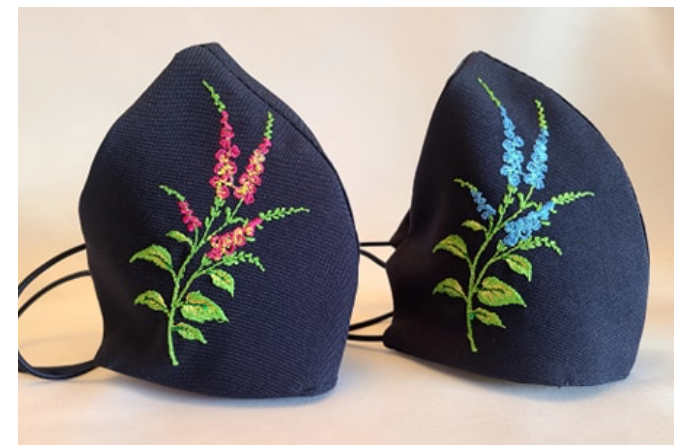

Image 3. An example of a modernized pattern of larkspur

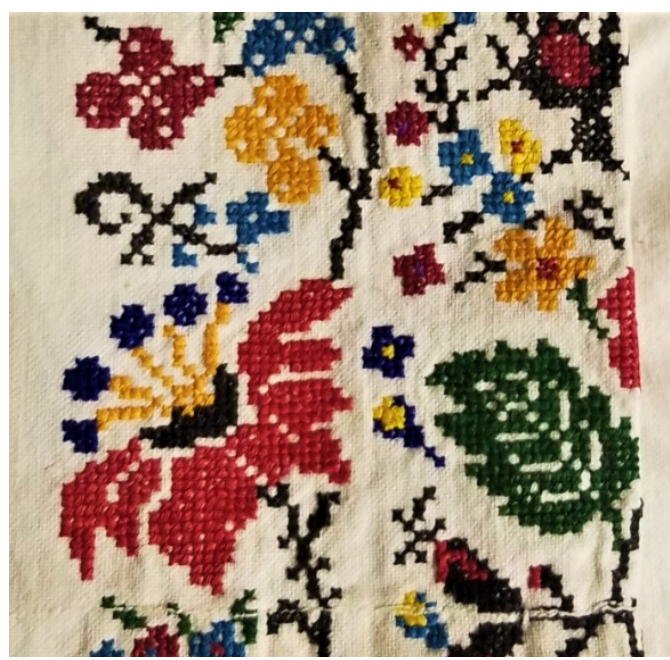

Image 2. A traditional example of larkspur combined with other botanical imagery on a woman's vyshyvanka c. 1950s from the

Bukovyna region. In collection at the Musée Ukraina Museum. who choose to wear and create the masks. In order to fully understand the ways in which face masks and embroidered PPE impact those who wear them and the worlds around them, it is important to first consider ways in which these two functions impact different aspects of life.

Emphasizing the role of embroidery within the Ukrainian Canadian diaspora in the 1980s, Klymasz provides more background into the nature of the open/performative function, discussing the importance of acknowledging the ways in which embroidery can act as a symbol of outward fidelity to one's culture. Within his understanding of the performative nature of the traditional folk craft, he acknowledges the necessity of the simplification and modernization of embroidery patterns and styles when included on cultural ephemera, a trend that is visible on many of the masks that have been created. However, Orysia Paszczak Tracz [1998] reminds researchers, embroiderers, and the general public that we must acknowledge the commercialization of the handicraft when presenting new styles and variants of traditional patterns, rather than simply equating the patterns as one and the same. By recognizing this, we are able to connect the original meanings to modern iterations and understand why 
these patterns are important and used today. It is necessary to simplify these patterns often for the sake of replicating them on non-traditional mediums like face masks, or when using non-traditional methods such as decalcomania and machine stitching. For example, image 2 depicts a portrayal of a generic larkspur plant, possibly the field larkspur (Consolida regalis) found in Ukraine and also known as del'finii, on a COVID-19 face mask. Image 3 depicts a more traditional embroidery pattern of larkspur in the top right corner, featuring multiple colors of pinks, blues and yellows on a long stalk, progressively getting smaller towards the top. The larkspur plant is rarely found alone in traditional patterns. Rather, it is often included in large floral designs with a number of flowers accompanying it. In order to make the pattern suitable for a mask, the single flower is simplified and enlarged to best fill the space of one side of a mask, as opposed to the use of a replicated pattern such as the one depicted in image 3 . That much larger motif only depicts a small version of the larkspur and runs the length of a woman's vyshyvanka sleeve. Many changes are present between the two styles, including the use of machine stitching on the mask as opposed to cross-stitching, to make the pattern more easily replicable and, therefore, more suitable for mass production. Additionally, the pattern including only the single flower is better able to be mass produced, as opposed to the manual labor required to create a large motif similar to the one in image 3 . While some artists have adorned entire masks with a single motif, the majority of masks featuring Ukrainian embroidery only display patterns on one side of the mask, or have two small matching patterns on each side, rarely covering the mouth with embroidery. At this time, it is unclear to me why this might be, however the shape and construction of the mask - often featuring a seam down the middle making it a difficult spot to evenly stitch overmay influence the choice of which patterns to replicate and how.

While pandemic wear is not a new phenomenon-masks were worn in the 1918 Spanish Flu epidemic and in 2009 to prevent transmission of the H1N1 Virus (3) - the prominence of PPE as a fashion object is relatively recent. The availability of differently styled and patterned face masks has increased as global communities share designs and products on digital marketplaces, and there is a clear chronology to that growth. Early in the pandemic, many digital marketplaces placed restrictions on the sale of medical masks and other high-demand objects, such as sanitizers, food items, and toilet paper. (4) Price restrictions were later placed on these objects, as several members of various digital communities began to overcharge for them, with one user from Sydney, Australia, selling a box of disposable face masks for the price of $\$ 500$. (5) Adam Mosseri, the head of Instagram, commented on the sale of these objects on Facebook Marketplace, in a now deleted tweet, saying "supplies are short, prices are up, and we're against people exploiting this public health emergency" [2020].

With new restrictions in place and the demand increasing for face masks, many artisans began to sew and create masks to sell on digital marketplaces for additional sources of income. This was especially true for many who had lost their jobs due to COVID-19. (6) The digital marketplace Etsy reported "\$346 million worth of masks [sold] during the pandemic, accounting for 14 percent of all sales 
across small sellers on the platform" [Hollister 2020. Emphasis in original]. On this platform, designer Dayna Konopelny, the owner of the shop EmilkaKono, began to sell Ukrainian-styled masks for a number of reasons, including "having people ask about [her] making them since it fit with [her] brand" [Konopely 2020]. As one of many sellers featuring culturally inspired facemasks, Konopelny utilized her digital market as a way to keep busy and generate income when her schooling and work abruptly ceased due to the pandemic.

The unprecedented world of face masks has been difficult to navigate, with information about the objects and their effectiveness changing frequently due to new research into the COVID-19 disease. (7) While this variability has caused a lot of confusion amongst members of the public, different marketplaces have worked to control disputes about advertised masks. For example, Vistaprint includes a disclaimer stating that "reusable face masks are not medical devices or personal protective equipment (PPE)" [Vistaprint 2020] in the product description for the cloth masks that they sell.

Due to the novelty of face masks as a fashion accessory, there is little prior research available regarding their stylization or their cultural trends. Thus, we must turn to other relevant areas of research that can aide in understanding this new fashion, such as the function of embroidery as a talisman or amulet [Odarchenko and Tsarynnyk 1991; Sciacca 2013; Khlystun 2015]. Similar to the Anglo-Saxon context, dating between 450-1100 AD, where embroidery was utilized as a means to "ward off evil and provide protection against unknown threats" [Lester-Makin 2019: 99], Ukrainian embroidery patterns have been traditionally "regarded with mystical awe and in many circumstances as magical and protective talismans" [Sciacca 2013: 2]. This concept is comparable to the "symbolic powers that could protect [a] wearer from evil and strife" [Kmit, Luciow, and Luciow 1984: 9] that are associated with the geometric, floral, and zoomorphic patterns of Ukrainian embroidery. The majority of scholars have studied these patterns in reference to the traditional rushnyk [ritual cloth], since that object is designed as a protective gift for the home. The continued use of these objects reveals that various applications of embroidery continue to carry these traditional meanings [see Image 4].

One prominent example of the talismanic nature of embroidery is visible in Olena Grigorivna Shevchenko's discussion of the use of a woman's traditional vyshyvanka, a traditionally embroidered blouse. Shevchenko notes that a "woman who [had] had a lot of children [would loan] her shirt to a woman who could not get pregnant" [2018: 121], with the shirt carrying an implied talismanic property that would aid in fertility. This shared belief that exists within Ukrainian culture demonstrates the ways in which material objects and patterns function within a unique realm of paganism that continues to exist alongside Christian belief, expressing the magical properties of symbols often tied to traditional deities such 
as Berehynia. (8) With masks, this belief is expressly visible when the symbols are used by designers and wearers alike as a protective symbol.

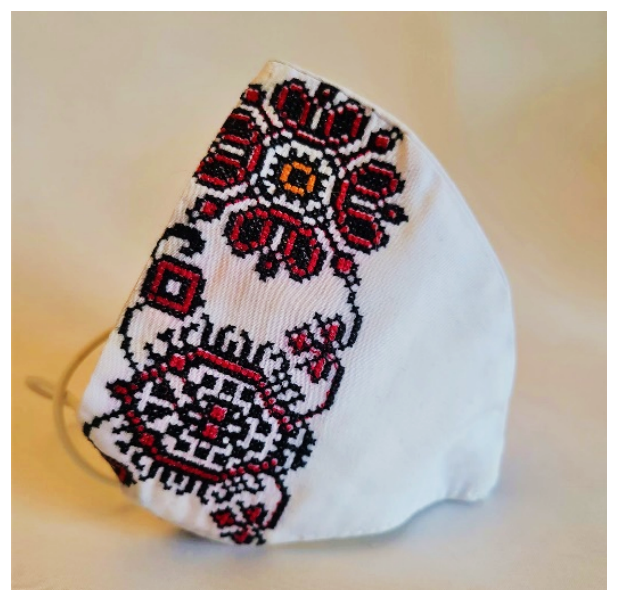

Image 4. The above mask features red and black cross-stitching in a traditional pattern. Stitching is limited to the first of three layers and only covers one side of the mask.

Ukrainian embroidery on masks is an especially interesting phenomenon to explore, as it occupies a unique space within the fields of folklore studies and material culture studies. The art form of embroidery is continuously evolving to accommodate the modernization of tastes and the industrialization of the craft. As noted by Anastasia Varyvonchyck, “останнє десятиріччя XX століття позначилося стрімким спадом... виробництв художніх промислів, не витримавши ринкової конкуренціï" [the previous decade of the twentieth century was distinguished by the quick decline... of arts and crafts, which were unable to withstand market competition] [2015: 250], largely due to the

introduction of the sewing machine.

Since this is a relatively new area of study, this research is based around the work of other scholars in the field of Ukrainian material folklore studies [Klymasz 1987; Lesiv 2013; Khanenko-Friesen 2015]. I build off of the work of these scholars in order to decode the mass popularity of current trends in embellished embroidery appearing on face masks and other PPE. By combining this research with further examination of different embroidery patterns in traditional Ukrainian culture [Dragan 1958; Hordynskyj 1948; Kelly 2003; Tsybul'ova and Havrylova 1982; Voznytsia 2005], this article emphasizes the connections that exist between the intentions of both creators and wearers of embroidered face masks, as well as the importance of the masks in a Ukrainian cultural context. For example, colors employed within Ukrainian embroidery were, and still are, often symbolic of the regions in which they are created, and not chosen purely for aesthetic appeal.

Moreover, the meaning behind each color employed, just as behind each pattern and motif, often effectively communicates cultural practices, truths, and knowledge which help preserve the history and tradition of the people. For instance, in Ukrainian tradition, white often symbolizes purity, integrity, and sanctity [Kelly 2003: 19], while red often symbolizes beauty, as the word krasnyi is used both to refer to the color red and the word beautiful. By connecting the symbolic meanings of patterns and colors to responses generated in my research, it is evident that the use of embroidery on masks still reflects these traditions, with the use of traditional colors on masks during the COVID-19 pandemic. 
Rooted in History: Ancient traditions in a Modern Pandemic

Having declared its independence on 24 August 1991, Ukraine as a nation state is relatively young in comparison to the rich traditions and cultures of the various regions and peoples who make up the country. Pre-dating the era of Kyivan Rus' of 882 C.E., the motifs popular in what is now considered traditional Ukrainian embroidery are seen in wall paintings depicting rituals of that time. Engravings in Trypillian pottery from the later Neolithic period (5000 - 2500 B.C.E.) provide depictions of clothing at that time that bear similar embroidery patterns to the ones used today. One such artifact depicts the "fertile field," [Kelly 2003: 13] a motif that "looks like a diamond with four dots in it, [which is] incised on the stomach of [a statue of a pagan] goddess indicating her pregnancy" [Kelly 2003: 13]. This same pattern is found today on pysanky (Ukrainian Easter eggs) as well as in embroidery motifs, including those added to masks.

A notable development in the use of traditional patterns of face masks is the wide variety of regional representation available. Artists, such as Iryna Khrystynych of Hoyra Studio, have attempted to create diverse patterns that represent a variety of regions, while still creating general patterns that represent the macro-culture of Ukraine [Forrest 2020]. Each region possesses its own style of embroidery, varying in thread color, technique, and pattern. The symbols and motifs found in Ukrainian embroidery can be divided into three main categories, including geometric, zoomorphic, and floral patterns. Within the realm of COVID-19 cultural ephemera, floral and plant patterns have become increasingly popular and appear most frequently on face masks. (9) Stylized flowers in clothing are used as a symbol to "protect against "evil spirits', misfortune and diseases" [Wasin 2021]. Ukrainian scholar Iuliia Nikishenko [2012] emphasizes the importance of the continuation of floral motifs in modern embroidery, drawing on the history of such symbolism within the culture, she writes:

\section{Рослинний світ—дерева, квіти, трави — міцно вкорінений у традиційній свідомості українського народу... вони $€$ неодмінними атрибутами лікувальних та магічних дій, родинно-побутових та календарних обрядів.}

[The world of plants - trees, flowers and herbs - is firmly rooted in the consciousness of the Ukrainian people... they are indispensable attributes of healing and magical actions, family and calendar ceremonies].

She emphasizes the importance of this symbolism not only in embroidery, but also on ceramic products, pysanky, and in petrykivka paintings (a traditional style of painting that dates back to the seventeenth century and is commonly used to decorate household objects, walls, and architecture). The use of specific motifs and styles not only helps communicate particular meanings but can also communicate the region from which that embroidery originates. For example, floral motifs are found in embroidery from northern regions, particularly Kyiv, 
while geometric patterns are found most commonly in the Hutsul region in the west.

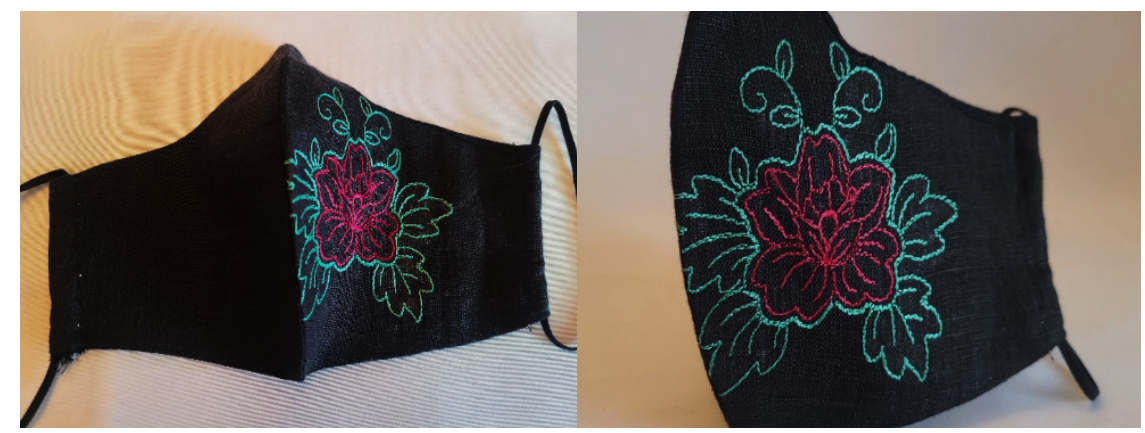

Image 5. This mask features an embroidery pattern of the mallow flower, or mal'va, known in folk tradition for its healing properties specifically for sore throats and dry coughs, symptoms associated with COVID-19

With floral patterns and plant life being some of the most prominent styles used to decorate Ukrainian COVID-19 face masks, it is important to understand the meaning of these patterns in order to grasp their relevance for the portrayal of macro-national identity in the open/performative function of embroidery. Mallow or mal'vy (malva), which is often embroidered in bright colors such as blues, reds, or pinks, symbolizes "love for native land, for nation and [the] people that represent it" [Krotenko 2018: 63], and is frequently found in the Zhytomyr region. The plant itself is used in folk medicine for sore throats and dry coughs. As these symptoms are also commonly associated with COVID-19, the use of this pattern on face masks seems particularly appropriate. The mask above in image 5 is a 3layer mask, with a machine-stitched embroidery pattern on the top layer. While the pattern could be identified as a number of different flowers, the designer lists this pattern simply as "chervona mal'va" [red mallow] without any further nomenclature provided about the chosen flower.

Another noteworthy pattern that has been modernized and replicated on face masks is that of the kalyna, or guelder rose [Viburnum opulus]. Known as an ethnic symbol of Ukraine, kalyna is prevalent in both traditional and modern folk songs such as Chervona Kalyna [Red Guelder Rose] and Odna Kalyna [One Guelder Rose], as well as in folk medicine, poetry, and in many other contexts. According to Orysia Paszczak Tracz [2001] "its beauty cannot be denied; its status in Ukrainian folk life is irreplaceable." The plant represents beauty, blood, love, 
womanhood, motherhood, and national resurgence; kalyna is "the color of the 'nation's soul,' the core of the Kozak spirit and the symbol of national unity" [Krotenko 2018: 73]. The depiction of kalyna has become increasingly important in recent years as a national symbol "expressive of Ukraine's yearning for freedom" [Balan 2016]. This proliferation is reminiscent of its role in the time of the communities of the kozaky

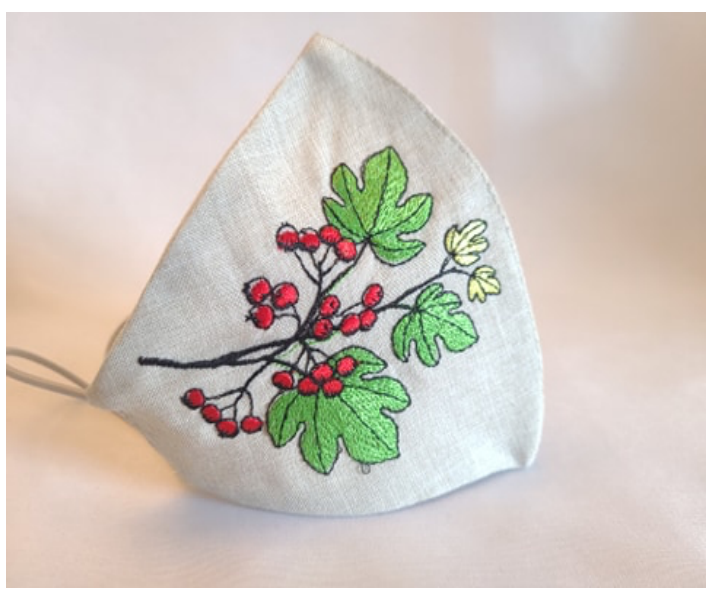

Image 6. This mask features a pattern of guelder rose or kalyna, a national symbol of Ukraine.

[Cossaks] in the sixteenth century when kalyna was used as a reminder of the motherland and "familiar places left behind" [Ukrainian Dance World 2014]. By displaying national symbols, such as the kalyna, on masks, people outwardly depict a macro-culture used to distinguish themselves from other nations and traditions.

By representing different regional embroidery patterns on masks, and by working to create a macro-representation of culture through the generalized use of these patterns, embroidered masks have acquired the attributes of folk motifs in embroidery, playing "a significant role in educating and stimulating... patriotic feelings [in] citizens of Ukraine" [Drozdova, Soroka, and Vityuk 2017]. The belief that these traditional motifs can be utilized for contemporary purposes comes to the forefront when one considers the role that embroidery played as a tool of protest during the Euromaidan Revolution of Dignity. (10) By infusing modern elements into traditional folk forms, Ukrainian embroidery has been adapted to accommodate "the new normal" of daily life. By incorporating these styles on face masks, national unity is displayed through the open/performative function of embroidery to outwardly exhibit cultural and national fidelity.

It is important to recognize the different shape and construction of masks in comparison to traditional vyshyvanky and rushnyky. This construction influences where embroidery can be placed, what patterns are feasible, and which types of stitching are more appropriate for certain areas on masks. For example, merezhka embroidery, a type of cut-and-drawn openwork embroidery that creates gaps in the fabric, is an inappropriate style for PPE, as it would be permeable. Masks have most commonly displayed either forms of cross-stitch or of lyshtva - also known as a leaf-stitch, a form of two-sided satin stitch with long single lines that appear nearly identical on the front and back of an item - even when they are not made with needle and thread embroidery. For example, masks that feature decalcomania 
still attempt to replicate the cross-stitch style, featuring patterns made up of little " $x$ "s or squares to mimic the appearance of the original stitching style. This representation of embroidery, while not truly embroidered, has been favored among many designers and healthcare professionals. Staff at the Kitsman Central District Hospital in Bukovyna and the Lviv Regional Clinical Hospital painted their protective suits to simulate embroidery patterns for International Vyshyvanka Day 2020, on 21 May, during the COVID-19 pandemic. (11)

Understanding the Appeal: Research Methodology

Because data collection is still in progress at the time of this writing, I have yet to receive a full range of responses. However, I am able to provide a number of valuable preliminary results to contextualize the research. Subsequent research will include data based on additional questionnaires. When more responses have been gathered, I intend to analyze trends based on gender identification, geographical location, and age. Due to the small sample size employed for this paper, analyses based on wider trends have proven impracticable and identifying distinctions between diaspora and national respondents has been difficult.

The first survey, distributed to artisans and designers, addresses the following questions:

1. Did you have experience with Ukrainian embroidery or Ukrainian folk art prior to the COVID-19 pandemic?

2. What inspired you to include Ukrainian motifs on your masks, or to sell masks featuring Ukrainian folk art?

3. Would you describe your patterns as traditional or as a modern interpretation/style?

4. Is your current work on masks influenced by the traditional meanings behind specific embroidery patterns or colors?

5. What does Ukrainian embroidery and folk art mean to you?

These open-ended questions are intended to evoke answers which will provide further information about each artisan's motivation for creating embroidered designs. They are also aimed at revealing the shift (if one exists) from other commercial products that feature embroidery to face mask production. The survey for artisans and designers has been distributed to 30 participants, with six having responded at this time.

Contact with members of the general public regarding mask wearing has been more successful, with 25 participants having responded to date. Having shared this survey through various public forums online and by word of mouth, 19 of the respondents have been from North American communities, while only six were residing in Ukraine at the time of their response. As I was living in 
Canada at the time of the research and had primarily advertised the questionnaire on digital English-speaking forums, there was a significantly higher response by North American participants than those in Ukraine. The following questions were asked of wearers of Ukrainian embroidered face masks:

1. Do you own any masks with Ukrainian embroidery, embroidery-like patterns, or Ukrainian folk art on them?

2. If so, what were your motivations for purchasing it/them?

3. Do you own other objects with Ukrainian embroidery or embroiderylike patterns on them? If yes, please list (i.e., embroidered clothing, housewares, etc.).

4. Are there any particular meanings that you associate with embroidery?

5. What does Ukrainian embroidery mean to you?

6. How do you feel/react when you see someone wearing traditional embroidery or embroidery-like patterns in person or in the media?

My preliminary findings allow us to gauge this phenomenon in its earliest forms. Not only do I intend to expand my survey to include more participants, but I believe this research should be expanded to include members of other cultures who also use face masks as a new medium for cultural representation through textiles.

Preliminary Results

Only half of the desired number of respondents have participated at this time in the consumer/general public survey, with 24 percent of those respondents from Ukraine and eight percent identifying as male. Additionally, of the six designers interviewed, five were residing in Ukraine at the time of the survey and only one was in Canada; all of these participants have been female. Thus, at this stage it is difficult to make distinctions based on gender or nationality without relying upon significant generalizations when analyzing the results for both the consumers and the producers of embroidered masks. Currently, respondents have provided a variety of answers to the questions, both confirming and expanding on my initial hypothesis. One motivation, which I had not previously considered, was the philanthropic effort to financially support community members through the purchasing of masks. For example, Jana Lalach purchased her masks in order to support a Ukrainian Orthodox children's camp through the funds raised by sales [Lalach 2020]. Another unexpected motivation was the wearing of masks to indicate family ties. With her mother creating the masks out of boredom and "for something to do during the pandemic" [Anonymous \#1 2020], one respondent 
said that she now wears the masks because they were created by her mother (See Image 7 for an example of the masks submitted by this respondent).

While one respondent who owns Ukrainian masks does not have any additional associations with embroidery, 24 respondents made up of both national and diaspora Ukrainians, had a range of associations. Based off the most commonly used phrases or words from each

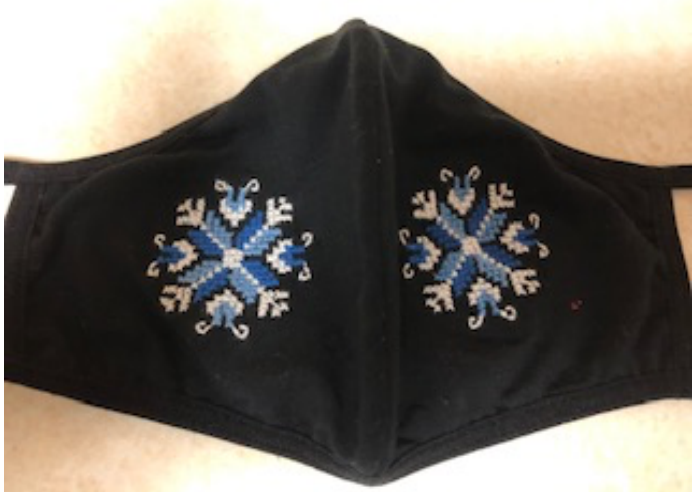

Image 7. This mask was created, and hand stitched, by a local woman in Saskatoon, SK. of the consumer respondents, I have compiled the following chart [Figure 1], depicting their associations. Each bar depicts how many respondents mentioned the listed item as an association with Ukrainian embroidery, both on masks and in general. So as not to influence opinions, I left the questionnaire open-ended for participants to write in their own responses, rather than pre-selecting "buzzwords" to choose from. Several respondents listed multiple associations with embroidery; therefore, there are more than 25 listed associations. However, the chart reflects that the majority of consumer respondents associated culture and heritage, as well as national pride with depictions of Ukrainian embroidery.

While I am hesitant to make any strong claims about connections between nationality and the responses due to the small sample size, four out of the five people who mentioned artistry and appreciation for craft as an association with embroidery were Ukrainian nationals. An equally common association is national pride, with four out of six Ukrainian nationals also mentioning this category.

In consideration of the open/performative nature of embroidery and face masks, the survey asked, "How do you feel/react when you see someone wearing traditional embroidery or embroidery-like patterns in person or in the media?" This question was answered by 60 percent of respondents with the word "proud." Associating cultural pride with the outward display of Ukrainian embroidery, participants noted that the display suggested a cultural connection and a sense of commonality between themselves and other wearers. Through these assumed connections held by witnesses to embroidery, the open/performative function of embroidery to promote tradition through ephemera and to assert cultural importance is evident. In contrast, only eight percent of respondents mentioned that they wore masks or associated them with spiritual protection, both secular and sacred, suggesting that fewer consumers recognized the traditional personal/private functions as motivators when choosing masks. 


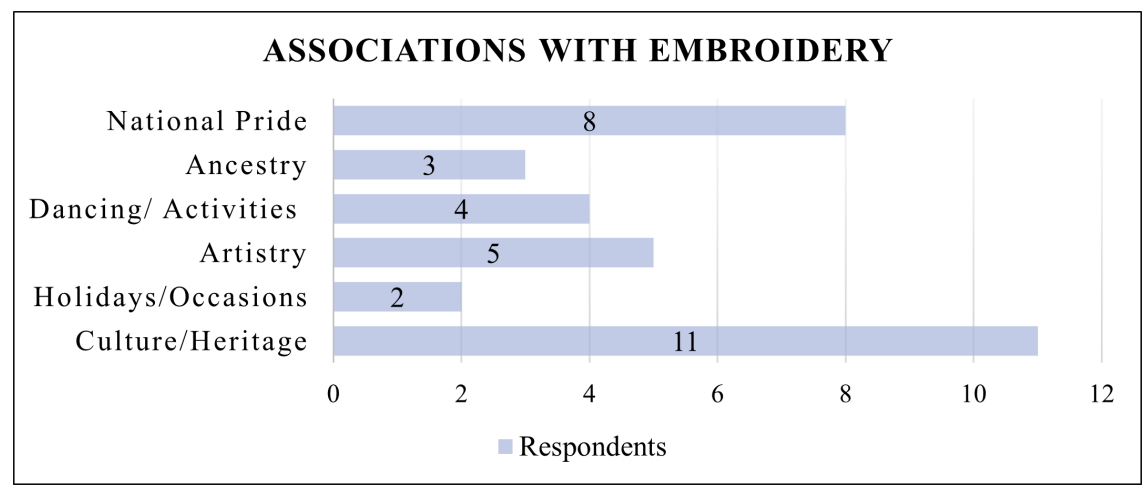

Figure 1. Respondent Associations with Embroidery

By comparing the answers from both designers and wearers, I have concluded that the element of protection is primarily recognized by the former of the two groups. Franklin Sciacca notes, in his article "Ukrainian Rushnyky: Binding Amulets and Magical Talismans in the Modern Period," that a late nineteenth-century ethnographer observed the creation of rushnyky during a time of plague as a ritualistic form of protection. Sciacca also highlights that "at the moment of passing under the sacred cloth the community is protected and born anew, disease is banished" [2013: 6], demonstrating that those who have created ritual objects are often responsible for the protection of their villages. This sentiment carries through to the mentality of artists today. When asked about the traditional talismanic properties of the embroidery on the face masks she creates, designer Anna Marchuk responded that "в кожній нашій вишивці є зміст" [in all of our embroidery there is meaning] [Marchuk 2020] and that the masks she had made were only for the use of her employees as a form of spiritual and physical protection.

More commonly, responses from both designers and wearers reflected on the visualization of national identity. For one respondent, wearing these masks is "a way to show off [her] heritage and pride for [her] Ukrainian cultural background" [Anonymous \#2 2020]. Participants who mentioned national culture as a motivating factor often owned a variety of objects with embroidery, including modern clothing, traditional costumes, vyshyvanky, rushnyky, and ceramic glassware. Seeing these masks on others also evoked "a huge sense of pride" [Heather 2020] that "inspired [respondents] to wear [these patterns] as well to showcase... [their] culture" [Senick 2020]. Seeing others wearing the masks also evoked a sense of relatability in respondents, suggesting that they and these strangers may share similar passions regarding culture, language, and history.

Journalist Steve Forrest recounts how Iryna Khrystynych, the designer behind Hoyra Studios in Lviv, stated that they create masks "for reasons of hygiene (so as not to touch one's face), psychology (to look good in difficult circumstances), and to support national pride" [2020]. Khrystynych notes that "embroidery is a symbol of our national identity and spirit; it's what I do best" 
[Forrest 2020], demonstrating that such nationalistic sentiments exist in designers, just as they do in wearers. With the market for modern Ukrainian embroidered clothing continuously increasing, it is evident that the trend of Ukrainian embroidered masks is not only a welcome one, but a positive one that promotes cultural identity and pride.

These preliminary results not only support but expand upon my original hypothesis, demonstrating that conceptions of patriotism, philanthropy, and fashion motivate both wearers and designers to engage with these products. Perhaps most notably, these responses demonstrate that it is the open/performative function of culture that acts as the most common motivation for engagement with embroidered PPE. The demonstration of pride, cultural allegiance, and promotion of tradition aligns with the "concomitant politicization" [Klymasz 1987: 4] that accompanies public displays of culture. In comparison, the personal/private function of the symbolic protection associated with the patterns is only mentioned by artisans as well as consumers who are Ukrainian nationals. This fact suggests that the personal/private function of embroidery is less prominent in diaspora than that of the open/performative functions. Furthermore, my research results reaffirm Klymasz's belief that "The closed/personal [or personal/private] category of milieu is almost totally eclipsed by the public function of Ukrainian embroidery, which is maintained chiefly as a form of open display to underline a fidelity to ethnic loyalty and origins" [1987: 4]. This overwhelming shift towards the open/performative functions of embroidery can be understood as politically motivated, in order to assert cultural distinction.

Being Seen to be Heard: Identity Politics and Masks

To better understand the utility of masks as a cultural object, it is necessary to first understand the symbols they are decorated with as a form of communicative media. The open/performative function of embroidery, and of material culture generally, places a heavy emphasis on visual communication. These objects are utilized in outward displays of culture. With the rapid increase of the availability of and demand for face masks due to the pandemic, masks have become, arguably, one of the most valuable forms of communicative media available at this time. One element that is prevalent in folk-art as a medium is that, while there are links and similar patterns shared between different cultures throughout the world and history, there are an infinite number of variants which make it nearly impossible to describe folk-art in specific terms. Therefore, we must consider masks as a broad representation of a macro-culture to understand such limitless terms. 
While some criticize the use of masks as "capitalism's newest product... [reducing] the people who wear them to walking advertisements" [Pawluk 2020], consumer responses to the mask survey suggest that masks have made a positive cultural impact as another way to advertise affiliation with one's culture and heritage. Using masks as a form of communication utilizes the performative function of embroidery to the fullest extent, with attention focused, quite literally, on the faces of those within and external to the culture who see these masks. One respondent to the consumer questionnaire from Saskatoon, SK, who was not Ukrainian and did not own a Ukrainian styled mask, noted that seeing the masks encouraged her to learn more about cultures she was not a part of [Gabby 2021]. Another commented that seeing others outwardly represent their culture inspired him to do the same [Anonymous \#3 2021].

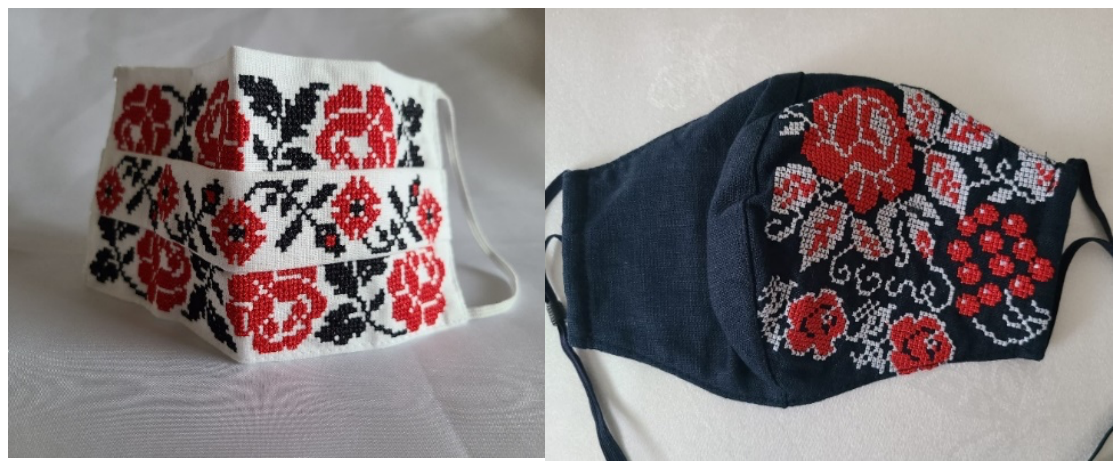

Image 8. Two examples of generalized Ukrainian face masks with black, red, and white color schemes, floral patterns, and cross-stitch style

Journalist Vladislav Inozemtsev attributes the collapse of the Soviet Union "not so much [to] economic crisis or ideological disillusionment following the end of communism as [to] its constitutive republics' attempt[s] to reclaim sovereignty all at once" [2017] However, the shift from these traditional meanings towards modern patterns that simply represent a macro-culture is just as valuable when considering the function of these face masks. With a current emphasis on the performative nature of embroidery, we must understand the shift away from regional representation through folk costume to a generalized national Ukrainian identity [see Image 8]. Myroslav Melnyk [2019: 110] emphasizes this shift as a "rejection of... social (Cossacks, serfs, farmers), religious (Orthodox, GrecoCatholics, Jewish), regional (Ruthenians, Boyky, Lemky, Hutsuls) and other identities [to the benefit of a] national concept of 'Ukrainian.'"

Tatiana Zhurzhenko addresses the roles of identity in Ukrainian politics, stating that there exists "a widespread anxiety about the lack of a strong "national identity" [that is] supposed to fill the ideological vacuum left after the collapse of communism" [2014: 249]. She notes the division between Ukrainian regions but discerns that it is not a useful narrative to pursue. However, "the "clash of civilizations' approach" [2014: 250] is precisely what is being used by the Russian 
and Ukrainian governments in present conflicts in order to create division amongst Ukrainian nationals. By creating one macro-Ukrainian identity, this approach is no longer validated. It is the conceptualization of a macro-identity through the modernization of traditional embroidery patterns that truly politicizes the use of Ukrainian styled face masks. With the Soviet Ukrainian identity never having fully disappeared, Ukrainian nationalism was considered to be a minority belief [2014: 252-253]. Yet, it is this nationalism that has grown through the polarizing events of the Euromaidan, the annexation of Crimea, and the war in Donbas. The identity of a unified and distinct Ukrainian people is now continuously recognized in the folk craft of traditional embroidery.

When examining the ways in which embroidery is represented on these face masks, there is an evident shift towards this generalized macro-identity. Looking at artists such as Anna Marchuk whose work reflects a more modern style of embroidery, we can see the ways in which the newer embroidery technique of cross-stitching has become identifiable as Ukrainian. Allowing artists to design and represent a number of patterns, the increased use of cross stitch, or crossstitch-like patterns, in floral motifs may be one of the most widespread identifiers of macro-Ukrainian identity. As mentioned earlier, floral patterns appear most frequently on masks depicting Ukrainian culture, and these generalized florals, often depicting roses, sunflowers, and poppies, are increasingly used to represent Ukrainian-ness. Flowers are seen in Ukrainian hair wreaths [vinok], petrykivka paintings, and on khustky, traditional Ukrainian scarves used to cover a woman's hair. While they were previously prevalent in embroidery, the overwhelmingly increasing floral patterns are being worn not only across Ukraine, with Hoyra Studio having "sent orders out to nearly every region of the country" [Forrest 2020], but also throughout the diaspora.

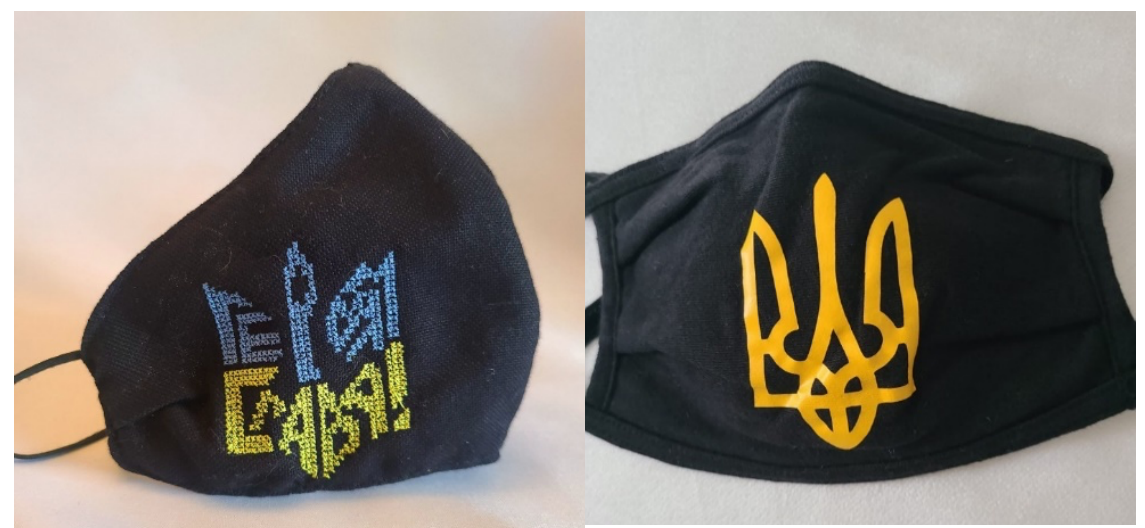

Image 9. Featuring the Ukrainian tryzub, or trident, the first mask reads "heroiam slava" [Glory to our Heroes]. The second features a decal of a tryzub, contrasting the cross stitching of the mask to the left. 
This drive towards the creation of a macro-identity has also culminated in the use of more non-traditional embroidery patterns or masks depicting different national symbols. While these masks are outside the scope of my research, as they do not have embroidery, traditional or otherwise, on them, they are worth mentioning when considering the open/performative function of cultural ephemera like COVID-19 face masks. One prominent symbol is that of the tryzub or trident, which is the coat of arms of the state of Ukraine [Image 9]. While the pattern can be found in some more modern forms of embroidery and infrequently in pieces from the Soviet period, it is not a traditional pattern. This symbol gained significant popularity during the Euromaidan. Orysia Paszczak Tracz [2016] states that the symbol was frequently used "during times of persecution (and there were so many), [as] one way of expressing patriotism and resistance" when incorporated into folk art. Paszczak Tracz states that the symbol was "anathema to the Russians, whether tsarist or Soviet," as it represented Ukrainian nationalism and separated the cultures of the two nation states.

With masks being used frequently to conceal identity, whether through folk traditions such as Malanka plays and Ukrainian carolling masks or in the form of the masked Russian aggressors known as the maskirovka, (12) the function of masks has been altered with the inclusion of these cultural symbols. With the use of masks as an outward performance of culture during COVID-19, the previously held concepts and ideas of masks being used to hide one's identity no longer exist in this context, temporarily having been subverted. Instead, consumers are proudly displaying their culture and being recognized by other members of the Ukrainian community by these symbols.

\section{Concluding Remarks}

The prevalence of the creation of a macro-identity through the revitalization and continuation of Ukrainian embroidery trends has enabled mask wearers to embrace the open/performative nature of displaying culture with everyday objects. Through the responses I have received to the survey to-date, the consumers wearing the masks are most frequently doing so in order to support their community and recognize their cultural heritage. Most importantly, by asking the respondents about their associations with embroidery, it became evident that the open/performative function of the patterns as a cultural identifier, has overshadowed the personal/private function of embroidery as a talismanic or protective symbol.

With the open/performative function, these masks are being worn for the sake of sharing one's cultural identity, as opposed to concealing it. This is done through the manipulation of traditional patterns by designating new meanings to the performance or display of the item. While this research has provided a preliminary look at the motivations to wear or create masks with traditional embroidery patterns, it has the potential to expand significantly to explore where these trends and responses are most prevalent and examine trends among different diasporic communities as well as different regions within Ukraine. As many 
cultures share the tradition of embroidery, this research could be further expanded to explore how different groups utilize traditional patterns on masks. Furthermore, the idea of understanding the beautification and politicization of personal protective equipment produces numerous questions when considering the approach taken to creating and wearing masks across a variety of cultures.

\section{NOTES}

1 This research does not address the effectiveness of masks or their scientific properties. For more information regarding the scholarly recommendations and studies regarding the use of facemasks in reducing the spread of the COVID-19 virus, see Chu, et. al (2020), and the advisories shared by the World Health Organization [World Health Organization 2020].

2 "Faux embroidery" is a term used by this author to describe the recreation of embroidery-like images through means which do not include a needle or thread. This includes decalcomania, painting, drawing, and similar means.

3 The use and effectiveness of face masks during different pandemics, such as the Spanish Influenza and the H1N1 virus is documented in the research of Cowling, et. al [2010].

4 Documentation on price gouging on digital platforms, including Amazon and Facebook, can be found in digital articles by Palmer [2020] and Hutchinson [2020].

5 See Hutchinson [2020] for further information on Facebook Marketplace pricing and specific examples.

6 For more information on face masks as a source of income, see Alie [2020], Hinds [2020], Homaid [2020], and Kaushik [2020].

7 On 29 February, the United States Surgeon General, Jerome Adams, tweeted "Seriously people- STOP BUYING MASKS! They are NOT effective in preventing general public from catching \#Coronavirus, but if healthcare providers can't get them to care for sick patients, it puts them and our communities at risk!" [U.S. Surgeon General 2020, emphasis in original]. Since this statement, more information has been released on the effectiveness of masks in reducing COVID19 transmission. For more information, see current WHO recommendations and Chu, et. al [2020].

8 For more information on the relationship between paganism and Christianity, as well as the role of paganism in modern Ukrainian life, see Lesiv [2013].

9 This observation is made by the author based on a collection of 55 different masks purchased from or donated by designers in Ukraine, the United States, and Canada.

10 For more information on the role of embroidery on fashion during the Euromaidan Revolution of Dignity, see Ferrier [2015].

11 Information about painted protective equipment is sourced from $B B C$ News Ukraine [2020]. 
12 For more information on maskirovky, see Thompson [2014].

\section{BIBLIOGRAPHY}

Alie, Terrique. 2020. "Face Masks is Proving to be a Viable Source of Income During Lockdown," The Jobsportal. Cited by https://www.thejobsportal.co.za/article/face-masks-proving-be-viablesource-income-during-lockdown. (consulted 22 December 2020).

Balan, Jars. 2016. "The Versatile Kalyna," Kalyna Country. Cited by http://www.kalynacountry.com/the-versatile-kalyna/. (consulted 10 March 2021).

BBC News Ukraine. 2020. "Вишиванка року: медики розмалювали свої захисні костюми" [Embroidered shirt of the year: doctors painted their protective suits]. BBC News Ukraine. Cited by https://www.bbc.com/ukrainian/news52757866? fbclid=IwAR2DX8dY1OpSslaFJ0S-FE6927R351mEoRkiG2gKokuyeDtoG6MOML 01c. (consulted 1 October 2020).

Chu, Derek K., Elie A. Akl, Stephanie Duda, Karla Solo, Sally Yaacoub, and Holger J. Schünemann. 2020. "Physical Distancing, Face Masks, and Eye Protection to Prevent Person-to-Person Transmission of SARS-CoV-2 and COVID-19: A Systematic Review and Meta-Analysis," Lancet 395 (10242): 1973-1987.

Cowling, B. J., Y. Zhou, D. K. M. Ip, G. M. Leung, and A. E. Aiello. 2010. "Face Masks to Prevent Transmission of Influenza Virus: A Systematic Review," Epidemiology and Infection 138 (4): 449-456.

Dragan, Rose. 1958. "Foreword," in Ukrainian Embroidery Designs and Stitches. Winnipeg, Manitoba: Trident Press, 9-12.

Drozdova, Veronika, M. Soroka, and Y. Vityuk. 2017. "National Motifs in Clothes as a Mean of a Patriot's Conscious Mentality Forming." Конферениії Державного університету «Житомирська політехніка» Cited by https://conf.ztu.edu.ua/wp-content/uploads/2017/05/274.pdf. (consulted 11 December 2020).

Ferrier, Morwenna. 2015. "In the Face of the Ongoing Conflict, Ukrainian Fashion is Having a Moment," The Guardian. Cited by https://www.theguardian.com/fashion/2015/apr/29/in-the-face-of-theongoing-conflict-ukrainian-fashion-is-having-a-moment. (consulted 11 October 2020).

Forrest, Steve. 2020. "Embroidered Masks - A COVID-19 Success Story," What's On. Cited by https://whatson-kyiv.com/embroidered-masks/. (consulted 10 December 2020).

Hinds, Eva. 2020. "Gender-based Violence Survivors Making Cloth Face Masks to Protect their Community: Empowered Women are using their Sewing Skills to Mitigate the Spread of COVID-19," UNICEF. Cited by https://www.unicef.org/somalia/stories/gender-based-violence-survivors- 
making-cloth-face-masks-protect-their-community. (consulted

December 2020).

Hollister, Sean. 2020. "Etsy Helped Sell \$346 Million Worth of Homemade Masks," The Verge. Cited https://www.theverge.com/2020/8/5/21356208/etsy-mask-sales-q2earnings-covid-19-coronavirus-2020. (consulted 9 September 2020).

Homaid, Mennatallah. 2020. "How Sewing Face Masks is Helping Displaced Women in Yemen." Reliefweb. Cited by https://reliefweb.int/report/yemen/how-sewing-face-masks-helpingdisplaced-women-yemen. (consulted 22 December 2020).

Hordynskyj, Wolodymyr M. 1948. A Brief Outline of Ukraine and Ukrainian Folk Arts. Munich: Association of former Ukrainian Political Prisoners.

Hutchinson, Andrew. 2020. "Facebook Bans Ads and Commerce Listings for Face Masks Due to Coronavirus-Related Price Gouging," Social Media Today. Cited by https://www.socialmediatoday.com/news/facebook-bansads-and-commerce-listings-for-face-masks-due-to-coronavirus-r/573691/. (consulted 7 December 2020).

Inozemtsev, Vladislav. 2017. "Russia, the Last Colonial Empire," The American Interest. Cited by https://www.the-americaninterest.com/2017/06/29/russia-last-colonial-empire/. (consulted 20 October 2020).

Karpovets', Maksym Viacheslavovych. 2018. Карповець, Максим Вячеславович. "Перформативна Теорія Культури: Повернення до Суб'єкта" [Performative Theory of Culture: Return to the Subject], Вісник Національної Академії Керівних Кадрів Культури і Мистецтв 4: 138145.

Kaushik, Divya. 2020. "Tailors Turn to Making Masks to Earn Income in Lockdown 4," The Times of India. Cited by http://timesofindia.indiatimes.com/articleshow/75978640.cms?utm_source =ground.news\&utm medium=referral\&utm source=contentofinterest\&ut $\underline{m}$ medium $=$ text\&utm campaign $=$ cppst. (consulted 7 December 2020).

Kelly, Mary B. 2003. Making and Using Ritual Cloths. New York: Studiobooks. Khanenko-Friesen, Natalia. 2015. Ukrainian Otherlands: Diaspora, Homeland, and Folk Imagination in the Twentieth Century. Wisconsin: The University of Wisconsin Press.

Khlystun, Olena Serhiïvna. 2015. Хлистун, Олена Сергіївна. “Символика Народного Искусства в Контексте Празднично-обрядовой Культуры Украинцев" [Symbolism of Folk Art in the Context of the Festive and Ritual Culture of Ukrainians], Вісник Національної Академії Керівних Кадрів Культури і Мистеитв 4: 88-92.

Klymasz, Robert. 1987. "Crucial Trends in Modern Ukrainian Embroidery," Material History Bulletin 26: 1-5.

Kmit, Ann, Johanna Luciow, and Loretta Luciow. 1984. Ukrainian Embroidery. Minneapolis: Litton Educational Publishing. 
Krotenko, Lidiia Borysivna. 2018. Кротенко, Лідія Борисівна. Time for Ukraine: Ukrainian National Symbols, Life style, Personalities. Куiv: Видво НПУ імені М. П. Драгоманова.

Kule Folklore Centre (Producer), Nahachewsky, Andriy (Director). 2011. What is Folklore? Episode 1: Definition. Cited by https://www.youtube.com/watch? $\mathrm{v}=\mathrm{r} 9 \mathrm{wLcOLtDkQ} \& \mathrm{t}=22 \mathrm{~s} . \quad$ (consulted 2 November 2020).

Lemiski, Shawna. 1994. "Ukrainian Embroidery in the Twentieth Century: Expressing a National Self Concept," Canadian Home Economics Journal 44 (2): 63-68.

Lesiv, Mariya. 2013. The Return of Ancestral Gods: Modern Ukrainian Paganism as an Alternative Vision for a Nation. Kingston, Ontario: McGill-Queen's University Press.

Lester-Makin, Alexandra. 2019. The Lost Art of the Anglo-Saxon World: The Sacred and Secular Power of Embroidery. Pennsylvania: Oxbow Books.

Melnyk, Myroslav. 2019. "Traditional Ukrainian Costume in the context of National Liberation and Soviet Occupation in 1920s," Вісник Черкаського університету 1: 109-115.

Mosseri, Adam [@mosseri]. 2020. We're banning ads and commerce listings selling medical face masks on Instagram and Facebook. Supplies are short, prices are up, Twitter. Cited by https://twitter.com/mosseri/status/1236118150514647040. (consulted 7 March 2020).

Nikishenko, Iuliia Ihorivna. 2012. Нікішенко, Юлія Ігорівна. “Символіка Рослинних Орнаментів Української Вишивки на Одязі Початку ХХ СТ” [Symbolism of Floral Ornaments of Ukrainian Embroidery on Clothing in the Early Twentieth Century]. Майстерня УКУРІКУК. Cited by http://ukurikuk.com.ua/article det/?id=22. (consulted 8 October 2020).

Odarchenko, Petro and Halyna Tsarynnyk. 1991. Одарченко, Петро. і Галина Царинник. Украӥнським Народний Одяг [Ukrainian Folk Costume]. New York: Printing Methods.

Palmer, Annie. 2020. “Amazon Sellers Fined for Price Gouging Hand Sanitizer amid Coronavirus Pandemic," CNBC. Cited by https://www.cnbc.com/2020/11/17/amazon-sellers-fined-for-coronavirusprice-gouging-hand-sanitizer.html. (consulted 22 December 2020).

Paszczak Tracz, Orysia. 1998. "Unraveling Embroidery: Part I," The Ukrainian Weekly LXVI (39): 7.

Paszczak Tracz, Orysia. 2001. "The Kalyna in Ukrainian Folk Medicine and Folklore," The Free Library. Cited by https://www.thefreelibrary.com/The+kalyna+in+Ukrainian+folk+medicine $+\% 26+$ folklore.-a0140997701. (consulted 20 December 2020).

Paszczak Tracz, Orysia. 2016. "The Tryzub is the New Meme," The Ukrainian Weekly. Cited by https://www.ukrweekly.com/uwwp/the-tryzub-is-the-new$\underline{\text { meme/. }}$ (consulted 22 December 2020). 
Pawluk, Mitchell. 2020. "Branded Face Masks: Turning Pandemic into Profit," The Gateway. Cited by thegatewayonline.ca/2020/05/branded-face-masksturning-pandemic-into-profit/. (consulted 18 March 2021).

Piniuta, Harry. 1978. Land of Pain, Land of Promise: First Person Accounts by Ukrainian Pioneers. Saskatoon, Saskatchewan: Western Producer Prairie Books.

Sciacca, Franklin. 2013. "Ukrainian Rushnyky: Binding Amulets and Magical Talismans in the Modern Period," Folklorica XVII: 1-35.

Shevchenko, Olena Vasylivna. 2018. "Ukrainian Folk Embroidery as A Way of Identification and Communicative Interaction of the Ukrainian People in Modern Conditions," Вісник Національної Академії Керівних Кадрів Культури і Мистеитв (3): 120-123.

Snikhovska, Kseniia. 2017. The Embroidery of Vyshyvanka: From Traditional Technique to Contemporary Technologies. Diss. University College of Southeast Norway.

Thompson, Mark. 2014. "The 600 Years of History Behind Those Ukrainian Masks," Time. Cited by https://time.com/67419/the-600-years-of-historybehind-those-ukrainian-masks/. (consulted 10 March 2021).

Tsybul'ova, Н. К. and Н. F. Havrylova. 1982. Цибульова, Г. К. І Г. В. Гаврилова. Ручне Вишивання [Hand Embroidery]. Київ: Техніка.

Varyvonchyk, Anastasiia Vitaliïvna. 2015. Варивончик Анастасія Віталіївна.

"Еволюція Розвитку Машинної Вишивки та Сучасних Вишивальних Автоматів" [Evolution of the Development of Machine Embroidery and Modern Embroidery Machines], Вісник Національної Академії Керівних Кадрів Культури і Мистецฺтв 4: 247-251.

Vistaprint. "Advanced protection. Layered filtration. Goes with everything." Vistaprint. Cited by https://www.vistaprint.com/masks/all/gray/. (consulted 8 December 2020).

Voznytsia, Ol'ha. 2005. Возниця, Ольга. Вишивка Мого Краю [Embroidery of My Country]. Львів: Дрогобич Коло.

Ukrainian Dance World. 2014. "The Symbolism of Kalyna in Ukrainian Culture." Ukrainian Dance World. Cited by https://www.ukrainiandanceworld.com/single-post/2014/11/21/thesymbolism-of-kalyna-in-ukrainian-culture. (consulted 20 December 2020).

U.S.Surgeon General [@Surgeon_General].29 February 2020.Seriously peopleSTOP BUYING MASKS! They are NOT effective in preventing general public from catching \#Coronavirus, but if healthcare providers... Twitter. https://twitter.com/Surgeon_General/status/1233725785283932160?ref_src $=$ twsrc\%5Etfw. (consulted 7 March 2020).

Wasin, Kasha. 2021. "Why the Poppy Picture? Symbolism of Flowers." Kasha Wasin. Cited by https://kashawasin.com/index.html. (consulted 10 March 2021).

World Health Organization. 2020. "Coronavirus Disease (COVID-19): Masks." World Health Organization. Cited by www.who.int/emergencies/diseases/novel-coronavirus-2019/question-and- 
answers-hub/q-a-detail/coronavirus-disease-covid-19-masks. (consulted 8 December 2020).

Zhurzhenko, Tatiana. 2014. "A Divided Nation? Reconsidering the Role of Identity Politics in the Ukraine Crisis," Die Friedens-Warte 89 (1/2): 249267.

\section{INTERVIEWS}

Anonymous \#1. Saskatoon, Saskatchewan, Canada. Responded to questionnaire. 17 December 2020.

Anonymous \#2. Edmonton, Alberta, Canada. Responded to questionnaire. 26 December 2020.

Anonymous \#3. Canada. Responded to questionnaire. 8 April 2021.

Gabby. Saskatoon, Saskatchewan, Canada. Responded to questionnaire. 6 April 2021.

Heather, Gloria. Location unknown. Responded to questionnaire. 28 December 2020.

Konopelny, Dayna. Toronto, Ontario, Canada. Interviewed through email communications. 16 December 2020.

Lalach, Jana. Saskatoon, Saskatchewan, Canada. Responded to questionnaire. 15 December 2020.

Marchuk, Anna. Location unknown. Interviewed over Facebook Messenger. 17 May 2020.

Senick, Zachary. Toronto, Ontario, Canada. Responded to questionnaire 29 December 2020. 